\title{
PELATIHAN : PENGELOLAAN KEUANGAN KELUARGA BAGI PEDAGANG DI PASAR BURUNG DEPOK SURAKARTA
}

\author{
Irwan Christanto Edy ${ }^{1)}$, Shandy Marsono ${ }^{2)}$, Supriyono ${ }^{3)}$ \\ STIE “Adi Unggu Bhirawa” Surakarta \\ Email : irwan_aub@yahoo.co.id
}

\begin{abstract}
Pasar Depok dikenal dengan Pasar Burung dan Pasar Ikan, merupakan pasar tradisional yang terkenal dengan pasar satwa seperti burung dan mamalia, namun yang paling dominan berupa burung. Permasalahan pokok di pasar Depok adalah manajemen sarana prasarana maupun manajemen usaha. Sebagian besar pedagang dalam mengelola usaha belum menerapkan manajemen usaha khususnya manajemen keuangan yang baik, usaha hanya dijalankan dengan mengandalkan konvensional. Aspek manajemen keuangan yang meliputi perencanaan usaha, pengorganisasian, implementasi, dan pengendalian usaha kurang diperhatikan para pedagang. Berdasarkan kajian situasi maka perlu penyelenggaraan kegiatan pelatihan manajemen keuangan khususnya perencaan keuangan yang dimulai dari keluarga kemudian berkembang ke bisnis. Hasil dari kegiatan ini para pedagang 1)memiliki motivasi, pemahaman tentang pentingnya perencanaan keuangan 2)memiliki pengatahuan tentang tabungan dan asuransi, 3)memiliki ketrampilan tentang Budgeting keuangan yang mulai dari keluarga. Kegiatan ini memberikan dampak yang signifikan terhadap peningkatan pengetahuan dan ketrampilan bagi pedagang di pasar Depok Surakarta.
\end{abstract}

Kata Kunci : Pasar Depok, Pelatihan, Manajemen Keuangan, Budgeting

\section{A. PENDAHULUAN}

Pasar Depok dikenal dengan Pasar Burung dan Pasar Ikan, merupakan pasar tradisional yang terkenal dengan pasar satwa seperti burung dan mamalia, namun yang paling dominan berupa burung. Terdapat berbagai jenis burung dan berbagai peralatan untuk memelihara burung seperti sangkar dan pakan burung. Luas area pasar cukup besar yaitu $12.754 \mathrm{~m}^{2}$. Pertama kali bangunan pasar kecil kemudian semakin kumuh, akhirnya pada tahun 2011 dilakukan revitalisasi pasar dengan konstruksi beton bertingkat (dua lantai) dengan pedagang keseluruhan 523 pedagang yang terdiri dari 64 pedagang kios, 226 pedagang los, serta 183 pedagang pelataran serta 42 pedagang ikan hias pindahan pedagang ikan Pasar Gede. Komiditas berupa satwa yang paling dominan adalah jenis burung. Selain burung terdapat reptil, ular, biawak, kelinci, anjing, dan kucing. Setiap hari pukul 8 pagi sampai pukul 4 sore. Mushola, MCK, Saluran IPAL, bank sampah, pengolahan limbah, bin sampah, CCTV, pusat informasi. Pengelola pasar yaitu pihak Dinas Pengelola Pasar (DPP) Kota Surakarta bekerjasama dengan 
paguyuban IKPBS (Ikatan Pedagang Burung Surakarta). Paguyuban berfungsi sebagai mediator antara pedagang dengan pihak pengelola, menyampaikan aspirasi dan permasalahan-permasalahan pedagang.

Permasalahan yang dihadapi oleh pedagang di pasar depok adalah manajemen usaha termasuk manajemen keuangan. Banyak pedagang yang mengelola usahanya tanpa memiliki dasar pengetahuan maupun ketrampilan perihal manajemen usaha dan manajemen keuangan yang baik. Tidak jarang usaha hanya dijalankan dengan mengandalkan insting dan pengalaman saja. Aspekaspek manajemen keuangan yang meliputi perencanaan usaha, pengorganisasian, implementasi, dan pengendalian usaha menjadi sesuatu yang jarang diperhatikan. Sebagian besar pedagang yang tidak melakukan pembukuan formal terhadap usahanya. Perhitungan laba sering dilakukan dengan sederhana tanpa melakukan analisis biaya secara memadai. Selama ini yang terjadi hampir sebagian besar pedagang tidak pernah menyusun dan pencatatan laporan keuangan usahanya secara berkala, apalagi membuat neraca rugi laba sehingga tidak pernah terpantau berapa nilai keuntungan secara riil atau nilai kerugian secara pasti manakala dagangnya merugi. Manajemen yang dilakukan pedagang adalah "manajemen saku".Yang disebut manajemen saku adalah segala pembayaran baik untuk upah, membayar barang, tukang sapu atau apapun semua dibayar langsung dari saku sendiri, tanpa ada pencatatan apapun.

\section{B. KAJIAN LITERATUR}

Definisi anggaran adalah suatu rencana yang disusun secara sistematis yang meliputi seluruh kegiatan perusahaan, yang dinyatakan dalam unit atau kesatuan moneter yang berlaku untuk jangka waktu yang akan datang (Munandar, 2001:11). Anggaran juga dapat diartikan sebagai istilah perencanaan untuk pengendalian laba menyeluruh dapat didefenisikan secara luas sebagai suatu anggaran sistematis dan formal untuk perencanaan, pengkoordinasian dan pengendalian tanggung jawab manajemen (Welsch, 2000:5). Nafarin, (2000:11) menyatakan bahwa anggaran merupakan rencana tertulis mengenai kegiatan suatu organisasi yang dinyatakan secara kuantitatif untuk jangka waktu tertentu dan umumnya dinyatakan dalam satuan uang, tetapi dapat juga dinyatakan dalam satuan barang maupun jasa. Dari beberapa pengertian anggaran merupakan rencana kerja sistematis yang dinilai dengan uang yang dibuat dalam bentuk angka-angka serta disusun dalam suatu atau beberapa periode tertentu yang dipakai sebagai alat perencanaan, pengkoordinasian yang terpadu dan pengendalian tanggung jawab manajemen melalui proses tertentu

Secara sederhana budgeting adalah proses menyusun anggaran, baik dana yang masuk maupun yang keluar. Lebih spesifik lagi terkait perencanaan keuangan keluarga, budgeting adalah proses menyusun dan merencanakan berapa banyak pendapatan yang hasilkan dalam periode waktu tertentu, dan berapa banyak pengeluaran yang akan dibelanjakan pada periode yang sama. Dengan melakukan budgeting, dapat melihat apakah keuangan saat surplus, impas, atau minus. Berita baiknya adalah: dengan budgeting, setidaknya kondisi setiap keluarga dapat dipaksakan supaya minimal impas. Kebiasaan Mencatat menjadi 
fondasi dasar perencanaan keuangan. Dengan mencatat maka mudah untuk mengetahui apa saja jenis pengeluaran dan pemasukan yang secara rutin.Secara umum budgeting untuk keluarga terdiri dari pengeluaran sebagai berikut:

\section{- Hutang}

Apakah memiliki kredit rumah, kredit mobil, atau lainnya? Tentukan berapa banyak yang harus keluarkan untuk masing-masing hutang tadi.

- Zakat, Infak dan Sadaqah

Sebagai seorang yang taat beragama dan menginginkan kebersihan dalam harta. Keluarkanlah zakat, infak maupun sadaqah. Dengan menghitung apakah sudah termasuk wajib zakat atau tidak dan budgetkan. Jika tidak, dikhawatirkan bagian dari harta yang harusnya dikeluarkan sebagai zakat tersebut dapat termakan dan mengurangi keberkahannya.

- Tabungan

Pos kedua setelah hutang adalah tabungan. Agar aman, budgetkan tabungan di awal dan anggap sebagai pengeluaran. Dengan demikian, tidak akan merasa berat untuk melakukannya. Jangan menabung dari sisa anggaran yang tersedia karena besar kemungkinan tidak ada sisanya.Termasuk tabungan di sini adalah sesuatu yang dipersiapkan untuk masa depan seperti: tabungan pendidikan, dana darurat dan lainnya.

- Konsumsi Rutin Bulanan

Bagian terakhir baru tetapkan untuk konsumsi rutin yang dikeluarkan mulai dari biaya pendidikan, belanja rumah tangga, dan tagihan-tagihan lainnya. Konsumsi rutin ini bisa dibagi dalam beberapa kategori. Berikut ini adalah contoh budgeting keuangan keluarga :

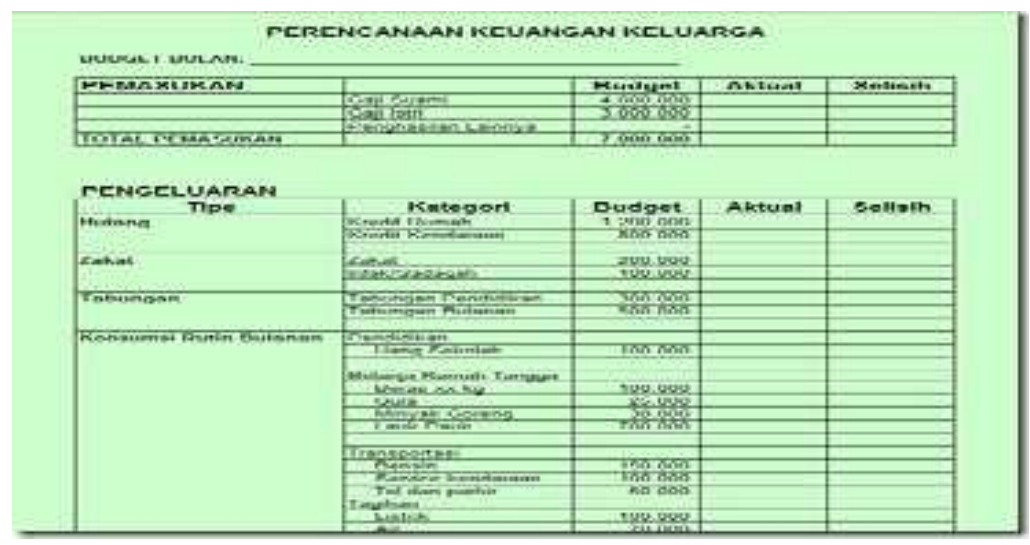

Gambar 1.Perencanaan Keuangan Keluarga

Pengelolaan keuangan adalah sebuah tindakan untuk mencapai tujuan keuangan di masa yang akan datang. Pengelolaan keuangan meliputi pengelolaan keuangan pribadi, pengelolaan keuangan keluarga, dan pengelolaan keuangan perusahaan. Pengelolaan keuangan merupakan bagian penting dalam mengatasi masalah ekonomi, baik masalah ekonomi individu, keluarga maupun perusahaan. Secara umum, tujuan dari pengelolaan keuangan meliputi : a)Mencapai target dana tertentu di masa yang akan datang, b)Melindungi dan meningkatkan kekayaan yang dimiliki,c)Mengatur arus kas (pemasukan dan pengeluaran uang), d)Melakukan manajemen risiko dan mengatur risiko dengan baik, e)Mengelola utang piutang. 
Setelah mengetahui tentang pengertian dan tujuan pengelolaan keuangan, yang harus diketahui adalah mengenai tahapan yang harus dilakukan dalam pengelolaan keuangan yang meliputi:

1. Pencatatan Aset/Harta yang dimiliki, setiap orang pasti memiliki aset/harta yang dicatat sebagai harta produktif maupun konsumtif, Harta produktif adalah harta yang memberikan penghasilan rutin atau keuntungan pada saat harta tersebut dijual kembali, Contohnya tabungan (yang tidak dipakai untuk belanja atau keperluan konsumtif ), deposito, reksadana, rumah (yang dikontrakkan bukan yang ditempati). Adapun harta konsumtif merupakan harta yang tidak memberikan penghasilan, baik penghasilan secara rutin maupun keuntungan ketika dijual kembali, Contohnya perlengkapan dan peralatan rumah tangga (televisi, meja makan, sofa, dan lain-lain), perhiasan yang dipakai, mobil, dan motor.

2. Pencatatan Semua Pemasukan dan Pengeluaran, setelah Anda mencatat semua aset/harta, Anda mendapatkan informasi tentang posisi keuangan Anda saat ini.Hal tersebut sangat berguna dalam melakukan langkah selanjutnya, yaitu mencatat semua pemasukan dan pengeluaran. Kegiatan mencatat semua pemasukan dan pengeluaranakan memberikan informasi tentang banyaknya uang yang telah masuk dan yang dikeluarkan. Hal tersebut menjadi pertimbangan bagi seseorang untuk mengontrol pengeluaran-pengeluaran yang tidak perlu.Pencatatan pemasukan dan pengeluaran juga membantu untuk mengetahui frekuensi pemasukan dan pengeluaran untuk suatu pos tertentu, sehingga dapat membedakan pengeluaran mana yang termasuk kebutuhan dan mana yang termasuk keinginan.

3. Identifikasi Pengeluaran Rutin Bulanan, dan Tahunan Setiap orang atau keluarga biasanya punya pola pengeluaran yang mirip dari bulan kebulan, termasuk dari tahun ke tahun. Setelah memiliki catatan pengeluaran, coba identifikasi apa saja yang menjadi pengeluaran rutin dan bagaimana frekuensinya. Kegiatan ini dilakukan untuk membuat pemetaan pengeluaran, apakah pengeluara tersebut sifatnya rutin bulanan atau tahunan, hal tersebut akan berguna sebagai bahandalam membuat perencanaan keuangan.

4. Menyusun Rencana Pengeluaran (Budgeting), Dalam menyusun rencana pengeluaran, hal-hal yang perlu diperhatikan, diantaranya sebagai berikut:1) Membedakan Kebutuhan dan Keinginan. Dari segi bahasa, "butuh" adalah kata sifat yang menunjukkan bahwa sesuatu mau tidak mau harus dipenuhi, karena kalau tidak dipenuhi akan mengganggu aktivitas sehari-hari, sehingga menjadi prioritas.Sementara "ingin" menunjukkan bahwa sesuatu yang diinginkan belum tentu dibutuhkan. Dengan kata lain,kebutuhan (need) adalah sesuatu yang sifatnya mendasar dan harus dipenuhi karena akan berpengaruh terhadap kelangsungan hidup, sedangkan keinginan (want) adalah kebutuhan yang sudah dipengaruhi oleh faktor lingkungan,pendidikan, selera, dan faktor lainnya dan tidak harus dipenuhi. Kebutuhan sesungguhnya bersifat relatif terbatas, sedangkan keinginan bersifat tidak terbatas. Dalam membuat perencanaan keuangan, seseorang harus cermat dalam memilah kebutuhan dan keinginan, sehingga tidak terjadi kesalahan pengalokasian anggaran, sehingga kebutuhan-kebutuhan 
mendasar dapat terpenuhi . Kebutuhan harus menjadi prioritas dibanding keinginan.

5. Pilihlah Prioritas Pengeluaran Terlebih, Dahulu Dalam menentukan prioritas pengeluaran, seseorang dapat membagi pos-pos pengeluaran kedalam tiga kelompok: Biaya Hidup, Cicilan Utang dan Premi Asuransi, Biaya hidup adalah semua pos pengeluaran yang biasa dilakukan seseorang agar dapat menjaga kelangsungan hidupnya, Contohnya membeli sembako, membayar telepon, listrik, air, biaya sekolah anak dan lain-lain, Adapun cicilan utang adalah semua pos pembayaran utang yang biasa dilakukan setiap bulan Seperti pembayaran cicilan rumah, cicilan kendaraan, cicilan kartu kredit dan cicilan-cicilan lainnya Menurut Aidil Akbar (2013), secara umum utang dapat dibagi menjadi utang produktif dan utang konsumtif. Utang produktif adalah segala jenis utang yang mempunyai ciri nilai aset yang dibeli dengan cara berutang dan meningkat seiring dengan berjalannya waktu, sementara utang konsumtif adalah segala jenis utang yang mempunyai ciri nilai aset yang dibeli dengan cara berutang dan menurun seiring dengan berjalannya waktu.Premi asuransi adalah semua pengeluaran yang dilakukan untuk membayar pengeluaran-pengeluaran asuransi seperti asuransi jiwa, kesehatan, dan asuransi kerugian (rumah dan kendaraan), Khusus untuk pos pengeluaran asuransi, biasanya tidak semua orang memiliki pos ini, premi asuransi biasanya hanya bagi mereka yang sudah memiliki pendapatan tertentu dan memahami pentingnya asuransi sebagai upaya prefentif dalam menanggung risiko di kemudian hari. Apabila semua pengeluaran ternyata masuk ke dalam tiga kelompok tersebut, maka harus disusun skala prioritas. Prioritas pertama adalah cicilan utang, karena cicilan utang mempunyai akibat tersendiri berupa denda.Selain itu saldo utang yang tidak dibayar tepat waktu akan terkena bunga. Prioritas kedua adalah membayar pos-pos premi asuransi, karena jika terlambat membayar akan mengakibatkan proteksi yang dimiliki dari program asuransi hilang .Prioritas ketiga adalah membayar biaya hidup, karena biaya hidup tidak akan menimbulkan bahaya jika terlambat membayar, misal belanja bulanan.

6. Menabung Secara Periodik Menabung sebaiknya dilakukan segera setelah mendapatkan penghasilan. Dengan demikian, begitu menerima pendapatan, sesuai rencana yang telah dibuat, segera simpan sejumlah tertentu untuk ditabung agar aman. Pisahkan rekening untuk tabungan dan bila perlu jangan dibuatkan ATM, sehingga Anda tidak tergoda untuk mengambilnya kembali.

7. Perencanaan Program untuk Masa Depan Rencanakan keperluan atau rencana khusus untuk masa depan. Perkirakan target periode pencapaian dan dana yang dibutuhkan. Setelah itu tentukan target dana yang harus disisihkan perhari atau perbulan. berikut :

Tahapan pengelolaan keuangan tersebut diatas dapat disajika sebagai 

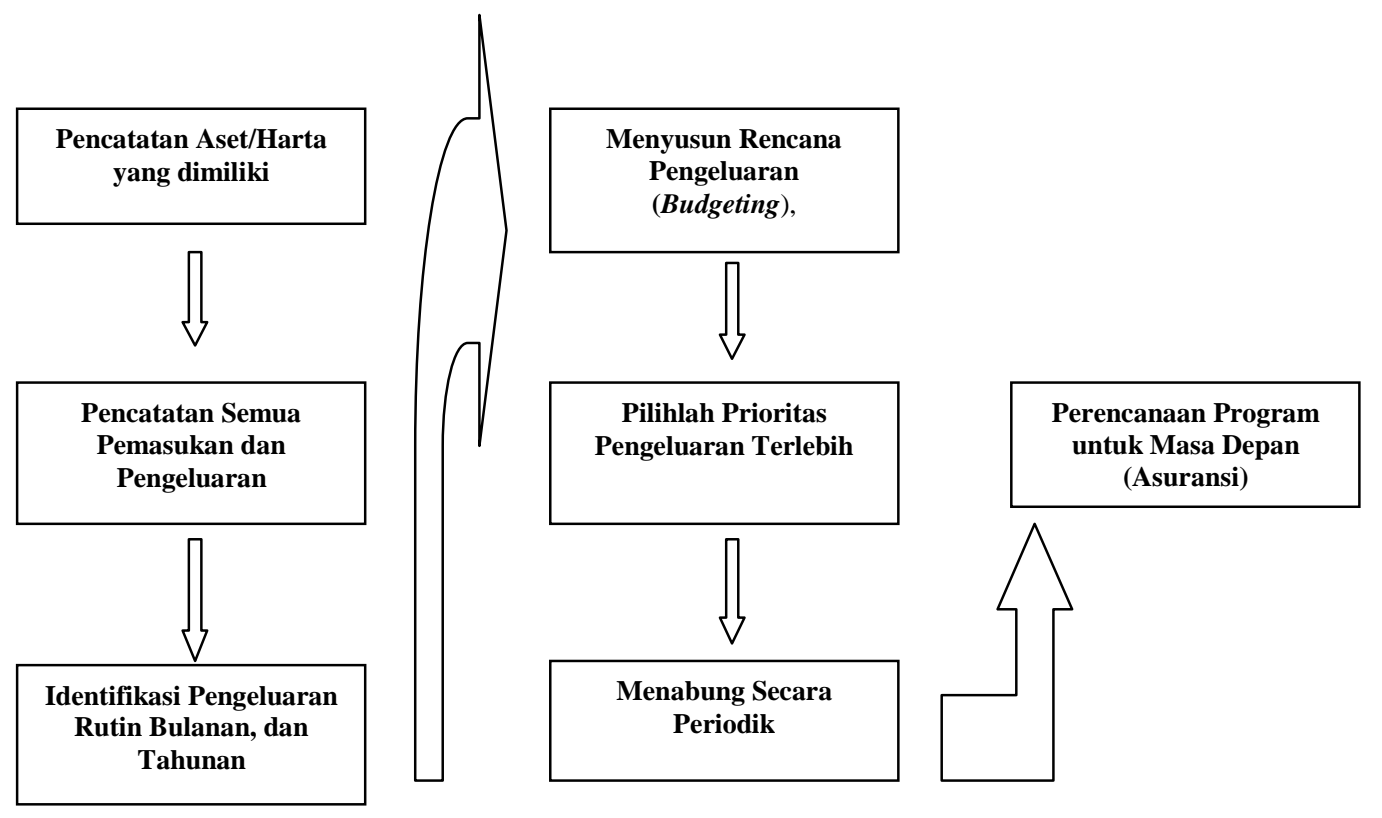

Gambar 2. Tahapan Pengelolaan Keuangan

\section{METODE KEGIATAN}

Adapun materi penyuluhan yang akan diberikan kepada para pedagang pasar depok Surakarta adalah : 1)Ceramah dan Pelatihan tentang pengelolaan keuangan, penyusunan anggaran, 2)Ceramah dan Pelatihan tentang tabungan dan asuransi, 3)Praktek budgeting untuk keuangan keluarga dengan aplikasi Excel. Dalam kegiatan pengabdian pada masyarakat ini, bentuk kegiatan yang digunakan mengacu pada kerangka pemecahan masalah sebagai berikut :

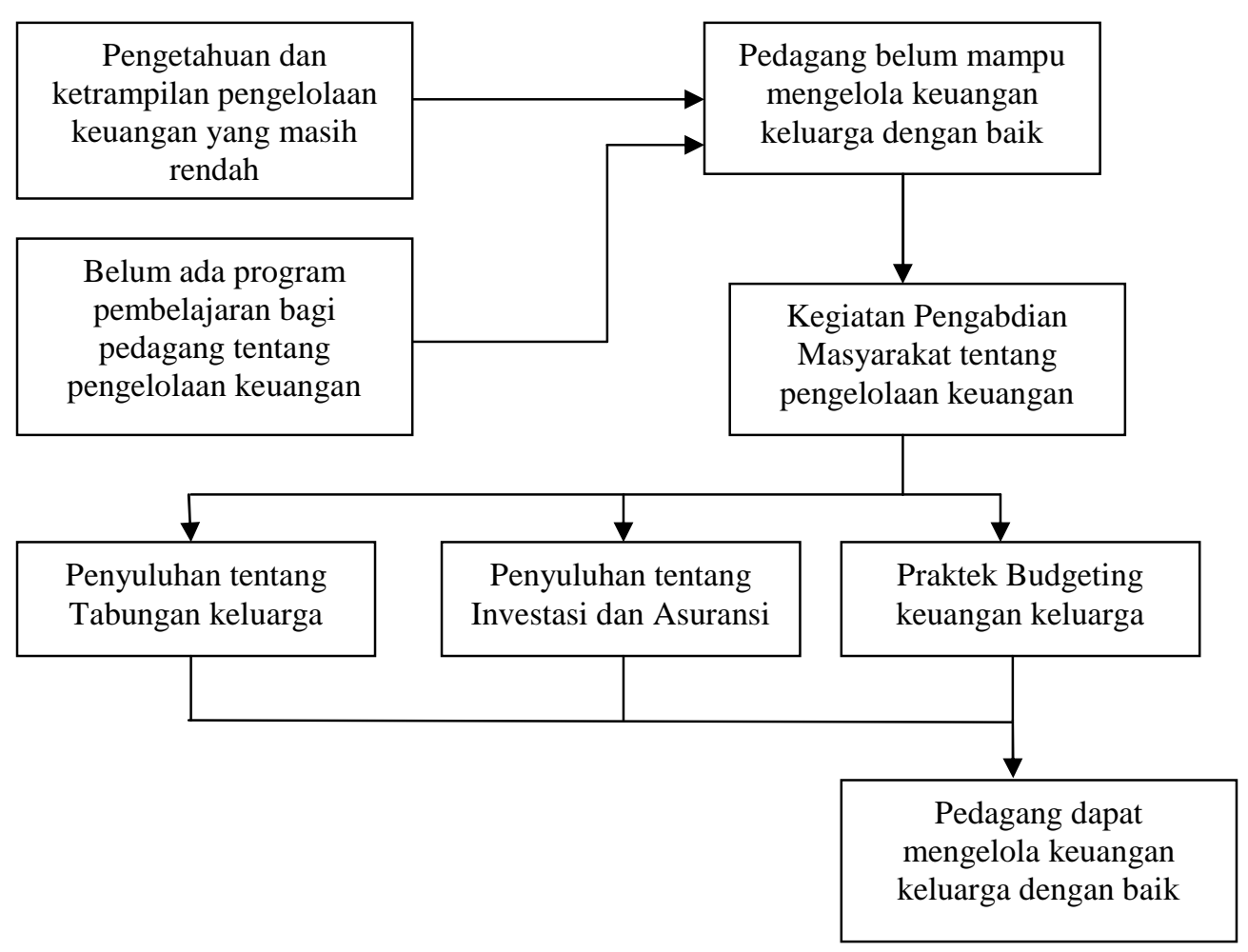


Sasaran dari kegiatan pengabdian pada masyarakat untuk pedagang di Pasar Depok Surakarta ini adalah : 1)Peningkatan pengetahuan dan ketrampilan pedagang dalam mengelola keuangan keluarga sehingga dalam hidup lebih sejahtera, 2)Memberikan edukasi terhadap pedagang tentang pengelolaan keuangan, 3)Memberikan ketrampilan tentang pengelolaan anggaran dalam keluarga. Bentuk evaluasi yang dilakukan dengan pengamatan, pengawasan dan wawancara tentang materi yang diberikan dalam penyuluhan dan praktek.Kriteria evaluasi adalah menjadi keberhasilan dari sasaran kegiatan khususnya penerimaan materi yang disampaikan dalam kegiatan. Sebagai tindak lanjut kegiatan ini adalah memberikan pendampingan bagi pedagang dalam menyusun anggaran (budgeting) dalam pengembangan usaha.

\section{HASIL KEGIATAN}

Kegiatan PPM yang dilaksanakan dengan acara tatap muka dan praktek tentang menyusun anggaran keuangan keluarga (Budgeting) berjalan dengan baik dan lancar. Pertemuan tatap muka dengan metode ceramah dan demonstrasi, dilanjutkan latihan/praktek untuk membuat perencanaan keuangan keluargga. Kegiatan ini dilaksanakan pada hari Sabtu tanggal 10 Juni 2017 dari pukul 17.00 sampai dengan selesai Peserta kegiatan berjumlah 29 pedagang yang tergabung pada paguyuban pedagang pasar burung Depok Surakarta. Pelaksanan kegiatan PPM ini dilakukan oleh 3 (tiga) orang tim pengabdi dengan pokok bahasan yang disampaikan mengenai:

1. Manajemen keuangan keluarga

2. Dana Masyarakat sebagai Sumber dana Pedagang Pasar Depok

3. Pengelolaan Keuangan Keluarga

Kegiatan yang diawali dengan ceramah dan diskusi ini kemudian dilanjutkan demonstrasi. Dari kegiatan ini tampak bahwa pedagang memang belum menguasai cara merencanakan anggaran keuangan keluarga dengan baik, khususnya penganggaran dan perencanaan keuangan dalam usaha. Acara kemudian dilanjutkan sesi tanya jawab.

Berbagai pertanyaan diajukan secara antusias oleh para peserta dalam sesi tanya jawab. Secara garis besar inti dari pertanyaan para peserta adalah: 1)Langkah langkah dalam penyusunan anggaran, 2)Langkah-langkah penyusunan budgeting. Program pengabdian pada masyarakat berupa pelatihan perencanaan dan pengelolaan anggaran bagi pedagang di pasar Depok, yang sudah dilaksanakan ini diharapkan dapat menambah pengetahuan, keterampilan dan lebih percaya diri dalam menjalankan usahanya. Pedagang akan lebih semangat dan termotivasi untuk mengembangkan diri. Hasil pelatihan ini akan bermanfaat bagi para pedagang khusus dalam mengelola keuangan usaha dan keluarga.

Hasil kegiatan PPM secara garis besar mencakup beberapa komponen sebagai berikut:

1. Keberhasilan target jumlah peserta kegiatan

2. Ketercapaian tujuan kegiatan

3. Ketercapaian target materi yang telah direncanakan

4. Kemampuan peserta dalam penguasaan materi 
Target peserta pelatihan seperti direncanakan sebelumnya adalah paling tidak 25 pedagang. Dalam pelaksanaannya, kegiatan ini diikuti oleh 29 orang peserta.Dengan demikian dapat dikatakan bahwa target peserta tercapai $100 \%$. Angka tersebut menunjukkan bahwa kegiatan PPM dilihat dari jumlah peserta yang mengikuti dapat dikatakan berhasil/ sukses. Ketercapaian tujuan kegiatan ini secara umum sudah baik, namun keterbatasan waktu yang disediakan mengakibatkan tidak semua materi dapat disampaikan secara detil. Namun dilihat dari hasil kegiatan ini para peserta merasa termotivasi untuk mengelola keuangan dengan baik, maka dapat disimpulkan bahwa tujuan kegiatan ini dapat tercapai. Ketercapaian target materi pada kegiatan PPM ini cukup baik, karena materi kegiatan telah dapat disampaikan secara keseluruhan. Kemampuan peserta dilihat dari penguasaan materi masih kurang dikarenakan waktu yang singkat dalam penyampaian materi dan kemampuan para peserta yang berbeda-beda. Hal ini disebabkan jumlah materi yang banyak hanya disampaikan dalam waktu sehari sehingga tidak cukup waktu bagi para peserta untuk memahami dan mempraktekkan secara lengkap semua materi yang diberikan. Secara keseluruhan kegiatan keberhasilan dapat diukur dari kepuasan peserta setelah mengikuti kegiatan. Manfaat yang diperoleh pedagang adalah dapat menyusun dan merencanakan keuangan dengan kualitas yang lebih baik.

\section{E. KESIMPULAN DAN SARAN}

1. Kesimpulan

Pasar Depok merupakan pasar tradisional yang terkenal dengan pasar satwa seperti burung dan mamalia, namun yang paling dominan berupa burung. Beberapa permasalahan muncul di pasar Depok adalah permasalahan sarana prasarana fisik maupun permasalahan yang manajemen usaha. Banyak pedagang yang mengelola usahanya tanpa memiliki dasar pengetahuan maupun ketrampilan perihal manajemen usaha dan manajemen keuangan yang baik bahkan tidak jarang usaha hanya dijalankan dengan mengandalkan insting dan pengalaman saja. Aspek-aspek manajemen usaha yang meliputi perencanaan keuangan, pengorganisasian, implementasi, dan pengendalian usaha menjadi sesuatu yang jarang diperhatikan oleh para pedagang.

Berdasarkan kajian situasi tim pengabdian pada masyarakat menyelenggarakan kegiatan pelatihan pengelolaan keuangan khususnya dalam merancang keuangan yang dimulai dari keluarga bagi pedagang pasar Depok Surakarta. Dalam program pengabdian pada masyarakat ini para pedagang 1)memiliki pemahaman tentang perencanaan keuangan khususnya tentang tabungan dan asuransi, 2)memiliki pemahaman tentang Budgeting keuangan dimana mulai dari lingkungan keluarga. Kegiatan ini telah berjalan dengan baik dan mampu meningkatkan motivasi dan pemahaman pedagang tentang perencanaan dan pengelolaan keuangan keluarga dengan baik.

\section{Saran}

Dalam kegiatan pengabdian berikutnya para pedagang perlu diberi pelatihan pengelolaan keuangan usaha yang menggunakan perangkat komputer. Para pedagang perlu mengoptimalkan pemanfaatan komputer untuk mengelola keuangan usaha dengan baik dan benar. 


\section{REFERENSI}

Bank Indonesia. (2013). Buku Panduan Guru Ekonomi SMA/MA Muatan Kebanksentralan. Jakarta

Hadiwijaya dan Rivai Wiasasmita. 1989. Manajemen Dana Bana. Pionir Jaya Bandung

Manullang.(1981). Pengantar Ekonomi Perusahaan. Yogyakarta; Liberty

Middlecamp,C.and Elizabeth Kean. (1985). Panduan Belajar Kewirausahaan . Jakarta: Gramedia

Mudrajat Kuncoro dan Suhardjona. 2002. Manajemen Perbankan. BPFE Jogjakarta

Pearce dan Robinson.(1997). Manajemen Strategik. Jakarta : Binarupa Aksara 